\title{
Higher MELD score increases the overall cost on the waiting list for liver transplantation: a micro-costing analysis based study
}

\author{
Jose Antonio Orellana TURRI ${ }^{1}$, Tassia Cristina DECIMONI ${ }^{2}$, Leandro Augusto FERREIRA ${ }^{3}$, \\ Marcio Augusto DINIZ ${ }^{4}$, Luciana Bertocco de Paiva HADDAD ${ }^{1}$ and Alessandro Gonçalves CAMPOLINA ${ }^{5}$
}

Received 7/3/2017

Accepted 10/4/2017

\begin{abstract}
Background - The pre-transplant period is complex and includes lots of procedures. The severity of liver disease predisposes to a high number of hospitalizations and high costs procedures. Economic evaluation studies are important tools to handle costs on the waiting list for liver transplantation. Objective - The objective of the present study was to evaluate the total cost of the patient on the waiting list for liver transplantation and the main resources related to higher costs. Methods - A cost study in a cohort of 482 patients registered on waiting list for liver transplantation was carried out. In 24 months follow-up, we evaluated all costs of materials, medicines, consultations, procedures, hospital admissions, laboratorial tests and image exams, hemocomponents replacements, and nutrition. The total amount of each resource or component used was aggregated and multiplied by the unitary cost, and thus individual cost for each patient was obtained. Results - The total expenditure of the 482 patients was US\$ 6,064,986.51. Outpatient and impatient costs correspond to $32.4 \%$ of total cost (US\$ 1,965,045.52) and 67.6\% (US\$ 4,099,940.99) respectively. Main cost drivers in outpatient were: medicines $(44.31 \%)$, laboratorial tests and image exams (31.68\%). Main cost drivers regarding hospitalizations were: medicines $(35.20 \%)$, bed use in ward and ICU $(26.38 \%)$ and laboratorial tests $(13.72 \%)$. Patients with MELD score between $25-30$ were the most expensive on the waiting list (US\$16,686.74 $\pm 16,105.02$ ) and the less expensive were those with MELD below 17 (US\$ 5,703.22 $\pm 9,318.68$ ). Conclusion - Total costs on the waiting list for liver transplantation increased according to the patient's severity. Individually, hospitalizations, hemocomponents reposition and hepatocellular carcinoma treatment were the main cost drivers to the patient on the waiting list. The longer the waiting time, the higher the total cost on list, causing greater impact on health systems.
\end{abstract}

HEADINGS - Health evaluation. Costs and cost analysis. Waiting lists. Liver transplantation.

\section{INTRODUCTION}

More than 2 billion people around the world have been infected by hepatitis $\mathrm{B}(\mathrm{HBV})$ and $\mathrm{C}(\mathrm{HCV})$ virus, resulting in approximately 400 million patients with advanced end chronicle liver disease. For the next 30 years, around $15 \%-40 \%$ of them will develop cirrhosis, hepatic failure, and hepatocellular carcinoma ${ }^{(30,34)}$. The annual expenditure with $\mathrm{HCV}$ and advanced liver disease comprises more than 32 billion dollars, with increases over time. The number of patients with viral hepatitis is growing annually and some studies estimated an increase of $60 \%$ of this amount in the next few years $^{(14,29,35,45)}$.

The pre-transplant period is complex and includes large quantities of procedures ${ }^{(19,22)}$. To date, previous studies have shown that the increased severity of liver disease predisposes to a high number of hospitalizations, high costs procedures increased morbidity and a high number of deaths ${ }^{(12,13,41,46)}$. Studies have shown that the cost of hospitalizations of patients with alcoholic cirrhosis overpass US\$ 8 thousand each stay. The annual cost of health care in this patient can reach 848 million dollars in the USA annually ${ }^{(12,13)}$. In
Brazil, the annual cost of heath care of each patient with advanced liver disease can reach more than 20 thousand dollars ${ }^{(1,2,11,27,28,38,44,49)}$.

Some correlated disease has strong linkage with high costs procedures and hospitalizations. Hepatocellular carcinoma is a malignancy associated with a high rate of mortality and costs ${ }^{(4)}$. Hepatocellular carcinoma (HCC) currently, affects $1.5 \%$ of the world population and reach approximately $15 \%$ of patients on the waiting list for liver transplantation ${ }^{(1,11,21)}$. Mishra et al. ${ }^{(28)}$ has demonstrated that the costs of treating patients with HCC in 2009 were around US\$ 31 thousand, with total treatment costs of approximately US\$ 2 billion in the USA.

Patient's severity, waiting time, high-cost procedures and medications, and hospitalization-related complications increase the number of employed resources and consequently the patient's costs, making these expenses increasingly important in the sum total of costs of these patients ${ }^{(2,14,46)}$.

The incorporation of new technologies has led to an exponential growth in health spending, resulting in increasing pressure for more efficient use of the limited resources available ${ }^{(2,3,36,38)}$. Tan ${ }^{(40)}$ has shown that differences in patient cost estimation parameters

Declared conflict of interest of all authors: none

Disclosure of funding: no funding received

${ }_{1}^{1}$ Departamento de Gastroenterologia, Faculdade de Medicina, Universidade de São Paulo, SP, Brasil; ${ }^{2}$ Departamento de Medicina Preventiva, Faculdade de Medicina, Universidade de São Paulo, SP, Brasil; ${ }^{3}$ Departamento de Estatística, Instituto de Matemática e Estatística, Universidade de São Paulo, SP, Brasil; ${ }^{4}$ Centro de Bioestatística e Bioinformática, Instituto de Estudos do Câncer Samuel Oschin, Los Angeles, Estados Unidos; ${ }^{5}$ Centro de Pesquisa Translacional em Oncologia, Instituto do Câncer do Estado de São Paulo, Faculdade de Medicina, Universidade de São Paulo, SP, Brasil.

Correspondence: Jose Antonio Orellana Turri. Departamento de Gastroenterologia, Faculdade de Medicina, Universidade de São Paulo. Av Dr. Enéas de Carvalho Aguiar, 455 - CEP: $01246-$ 903 - São Paulo, SP, Brasil. E-mail: antonioturri@usp.br 
can lead to differences between $€ 855$ and $€ 3221$ in the cost per day with hospitalizations.

In studies carried out with micro-costing methodology, all the relevant components and resources are individually raised to the highest level of detail possible ${ }^{(7,9,10,23,39)}$. This methodology increases the accuracy of the cost estimate and reflects the truthful use of the resources and their economic value through the detailed data collection of each resource used and the unit value of these resources ${ }^{(48)}$. Lack of detail, bias or underestimated analysis of costs may result in failures in the cost evaluation of diseases or programs under analysis with considerable implications ${ }^{(5)}$.

There is a growing interest of governments and health systems in economic evaluation studies that can improve the way in which limited budget resources allocated to patient care are shared out $^{(8,15,37,42,47)}$. Health technology assessment helps to achieve this purpose, making it possible to identify areas that require more investment and interventions associated with higher costs. The objective of this study was to determine the total cost of patients on the waiting list for liver transplantation and the resources that caused a greater impact on these costs, using micro-costing methodology.

\section{METHODS}

This was a prospective cohort study that included all patients on waiting list for liver transplantation attended at Clinics Hospital, Sao Paulo Medical School (HC-FM-USP) between January 2012 and December 2013. An economic evaluation study using microcosting methodology was carried out. The hospital perspective was taken in the measurement of resource use and costs by patients within the follow-up.

For each patient included in this study, patient demographics, clinical and overall cost were obtained. The amounts of resources (in units) were obtained using datasheet developed specifically for this study and individual data for each patient were registered. The follow-up period was individually calculated by the inclusion date of the listed patient until one of the following outcomes: list removal for improvement or worsening of the clinical health status, death, hospitalization for transplantation or completion of the study.

The MELD (Model of End-Stage Liver Disease) values were calculated for each patient on the day of enrollment and on the first day of hospitalization using the logarithmic formula of the results of the creatinine, total bilirubin, and INR tests.

$[\mathrm{MELD}=3.78[\mathrm{Ln}$ serum bilirubin $(\mathrm{mg} / \mathrm{dL})]+11.2[\mathrm{Ln} \mathrm{INR}]+9.57[\mathrm{Ln}$ serum creatinin $(\mathrm{mg} / \mathrm{dL})]+6.43]$

Four groups of patients were formed according to their MELD score severity based on the quartiles. This approach was carried out to better separate the groups with fewer outliers values and reach a better homogeneity intra quartiles.

The amounts of resources were directly obtained from different care sectors.

The total amount of medication used per patient was obtained by the hospital pharmacy sector through a computerized prescription system and number of materials used were obtained from a data sheet developed for this study and filled in by the Nursing Service during the patient's hospitalization. The quantities of laboratory tests and imaging were obtained directly in the electronic patient's database. The total number of consultations performed by medical and non-medical professionals was obtained directly from the electronic database of each patient. Regarding nutrition, the total quantities of diets received were obtained directly from the patient's electronic database by medical prescription. The total amounts of paracentesis, flasks, and albumin used per patient were provided directly by the nursing service of this sector. The amounts of dialysis performed were obtained from the patient's electronic database. The total amount of blood bags received per patient in hospitalizations were obtained directly in the electronic medical database of the hospitalized patient.

\section{Cost data}

The costs of each resource represent the costs of purchasing inputs and services by the hospital and do not represent the "full" price practiced by the pharmaceutical service or other market research inputs. Indirect costs were not included in this study. All costs were added together for the calculation of total cost per patient. Resources were divided into outpatient costs and hospitalization costs.

Outpatient costs included all services related to medical, dental, psychological, nutritional, nursing and social service consultations per patient were quantified and analyzed. We also considered the costs of procedures such as paracentesis and dialysis, materials, medicines, laboratory and imaging tests. Inpatient charges included all costs related to materials, medications, laboratory and imaging exams, procedures performed, blood transfusions, the length of stays and costs related to nursing and ICU diaries were quantified and analyzed.

The cost values of medication and materials were obtained from the Materials Administration System (MAS), where updated values of the last trading sessions paid for each item are recorded. The cost values of each image examination were obtained from the specialized department of each sector. The cost values of each laboratorial test were obtained at the hospital's central laboratory. Human resources costs were obtained directly from the administrative and managerial sector of the hospital and were calculated by the total amount of the wages received (including vacations, 13th salary, premiums, overtime surcharges, and withdrawals, etc.) divided by the total number of visits monthly and by the time spent in each service. The values of each type of enteral diet were determined by the Division of Nutrition and the values for parenteral diets were determined by the Division of Pharmacy. The values of each resource used for paracentesis, ambulatory dialysis and dialysis in hospitalization were provided by the Material Administration System (MAS) and directly by the department responsible for the procedure. The values of each blood component were obtained directly from the Hemotherapy Department through the administrative systems of cost management in this sector.

Procedures related to the treatment of hepatocellular carcinoma were obtained directly from the Institute of Cancer of the State of Sao Paulo (ICESP) using the methodology of absorption costing. The amounts of procedures performed and the costs were provided by the electronic databases of this hospital and are related to all resources and services used for each procedure, human resources, materials and related drugs and divided by the number of patients attended.

The total number of hospital bed days were obtained directly in the patient's electronic database and included the number of days in the ward and in the ICU for each patient. The calculation 
of the cost of daily hospital bed included amounts spent by the sector on human resources, specialized cleaning services, cloakroom sterilization, electric power, medical gasses and telephone calls. The total cost was obtained and values of bed use were calculated and divided for the number of patients attended.

\section{Statistical analysis}

Statistical analysis was performed using the $\mathrm{R}$ software version $3.3 .1^{(33)}$. In all cases, the level of significance considered was $5 \%$. The categorical data were presented in percentages and the cost data were presented in averages, standard deviations, and ranges.

To analyses the cost differences by the MELD groups was performed using the ANOVA test for variables that follow a normal distribution (Anderson-Darling test) and for variables that do not follow normality, the Kruskal-Wallis test. The assumption of Normality was verified by Anderson-Darling test and homogeneity of variances by Levene test. Multiple comparisons were done by Tukey's parametric and non-parametric tests.

For comparative analysis, in addition to the total values, the costs per day (total cost/day) and the costs per day in hospitalization (hospitalization cost/day) were also presented.

\section{RESULTS}

In this study, 482 patients were regularly included on the waiting list for liver transplantation. Among them, 134 patients were trans- planted (27.8\%), 103 patients were removed from the list $(21.4 \%)$, 66 patients died $(13.9 \%)$ and 179 patients $(36.9 \%)$ remained on the list until the end of the study.

The most frequent etiology was cirrhosis caused by hepatitis $\mathrm{C}$ virus (HCV) in 187 patients $(38.8 \%)$, followed by alcoholic cirrhosis in $152(31.5 \%)$. There were 301 male patients $(62.4 \%)$ and 181 female patients $(37.6 \%)$. There were 277 patients requiring hospitalizations $(69.25 \%)$, with 412 admissions in total and an average of 1.4 hospitalizations per patient. The clinical and demographic data of patients divided by MELD group, procedures performed, waiting time and numbers of hospitalizations are presented in Table 1.

Patients were divided into four groups by MELD score to verify the differences in cost. 132 patients had MELD below or equal to $17(27.39 \%), 122$ patients with MELD between 18 and 24 (25.31\%), 113 patients with MELD between 25 and $30(23.44 \%)$ and 115 patients with MELD above 30 (23.86\%).

The total expenditure of the 492 patients followed by 24 months on the waiting list for liver transplant was US\$ 6,064,986.51 and of these total, (US\$ 1,965,045.52) 32.4\% cost in outpatient care and (US\$ 4,099,940.99) $67.60 \%$ cost in hospitalizations.

In outpatient care, there were 10,638 consultants in physician and medical team $(8.96 \%$ of total cost), 167,182 laboratory tests and image exams $(31.68 \%$ of total cost), 3,062,209 unitary doses of medicines and drugs ( $44.31 \%$ of total cost). In hospitalizations, there were 5,017 days of stays ( $26.38 \%$ of total cost), 276,890 laboratory tests and image exams $(16.72 \%$ of total cost) and

TABLE 1. Clinical and epidemiological data of patients divided by MELD group $(\mathrm{N}=492)$

\begin{tabular}{|c|c|c|c|c|c|c|c|c|c|c|c|c|c|c|}
\hline & \multicolumn{3}{|c|}{$\begin{array}{c}\text { MELD < }=17 \\
(\mathrm{n}=132)\end{array}$} & \multicolumn{3}{|c|}{$\begin{array}{l}\text { MELD 18-24 } \\
\qquad(n=122)\end{array}$} & \multicolumn{3}{|c|}{$\begin{array}{l}\text { MELD 25-30 } \\
\qquad(\mathrm{n}=113)\end{array}$} & \multicolumn{4}{|c|}{$\begin{array}{c}\text { MELD > } 30 \\
(\mathrm{n}=115)\end{array}$} & \multirow[b]{2}{*}{$P$ Value } \\
\hline & Average & Sd & Range & Average & \multirow{2}{*}{$\frac{\text { Sd }}{14.0}$} & Range & Average & Sd & Range & Average & Sd & \multicolumn{2}{|c|}{ Range } & \\
\hline Age & 52.5 & 13.4 & $(19-86)$ & 51.9 & & $(19-80)$ & 55.4 & 10.7 & $(21-72)$ & 50.2 & 13.5 & & & 0.02 \\
\hline BMI & 25.6 & 5.1 & $(14.7-42.9)$ & 25.6 & 4.5 & $(18.5-36.3)$ & 25.9 & 5.0 & $(16.1-43.6)$ & 26.6 & 6.0 & (16. & & 0.86 \\
\hline MELD & 13.8 & 3.0 & $(6-17)$ & 20.8 & 2.1 & $(18-24)$ & 28.2 & 1.6 & $25-30$ & 36.5 & 4.4 & & & $<0.001$ \\
\hline Time on list (days) & 322.6 & 205.6 & $(4-730)$ & 287.8 & 201.5 & $(3-730)$ & 322.0 & 216.8 & $(1-730)$ & 173.4 & 210.2 & $(1$ & & $<0.001$ \\
\hline \multicolumn{15}{|l|}{ Inpatient stay (days) } \\
\hline Ward & 10.9 & 11.5 & $(1-51)$ & 18.1 & 20.6 & $(1-93)$ & 17.5 & 19.8 & $(1-95)$ & 16.2 & 19.8 & $(1$ & & 0.42 \\
\hline ICU & 6.4 & 9.1 & $(1-37)$ & 8.3 & 5.7 & $(1-18)$ & 10.8 & 11.7 & $(1-45)$ & 9.9 & 7.0 & & & 0.06 \\
\hline \multirow[t]{2}{*}{ Average days of stay } & 13.0 & 16.0 & $(2-74)$ & 21.0 & 23.5 & $(1-100)$ & 21.3 & 25.1 & $(1-114)$ & 20.2 & 19.8 & & & 0.13 \\
\hline & \multicolumn{2}{|c|}{ Total } & $(\%)$ & \multicolumn{3}{|c|}{ Total } & & Total & $(\%)$ & \multirow{2}{*}{\multicolumn{3}{|c|}{ Total }} & \multicolumn{2}{|c|}{$(\%)$} \\
\hline \multicolumn{12}{|l|}{ Sex } & & & \\
\hline Male & \multicolumn{2}{|c|}{89} & 67.4 & \multicolumn{3}{|r|}{60.7} & \multicolumn{3}{|r|}{62.8} & \multicolumn{3}{|r|}{67} & \multicolumn{2}{|c|}{58.3} \\
\hline Female & 43 & & 32.6 & & 48 & 39.3 & & 42 & 37.2 & & & 48 & 41 & .7 \\
\hline Etiology & & & & & & & & & & & & & & \\
\hline $\mathrm{HCV}$ & 30 & & 22.7 & & 33 & 27.0 & & 25 & 22.1 & & & 23 & 20 & .0 \\
\hline $\mathrm{HCV}+\mathrm{HCC}$ & 1 & & 0.8 & & 10 & 8.2 & & 34 & 30.1 & & & 18 & 15 & .7 \\
\hline Alcoholic & 52 & & 39.4 & & 21 & 17.2 & & 14 & 12.4 & & & 20 & 17 & .4 \\
\hline Other & 49 & & 37.1 & & 58 & 47.5 & & 40 & 35.4 & & & 54 & 47 & .0 \\
\hline Hospitalization & & & & & & & & & & & & & & \\
\hline Yes & 42 & & 31.8 & & 68 & 55.7 & & 82 & 72.6 & & & 85 & 73 & 9 \\
\hline No & 90 & & 68.2 & & 54 & 44.3 & & 31 & 27.4 & & & 30 & 26 & 1 \\
\hline $\begin{array}{l}\text { Number of } \\
\text { hospitalizations }\end{array}$ & 57 & & 13.8 & & 95 & 23.1 & & 132 & 32.0 & & & 128 & 31 & .1 \\
\hline $\begin{array}{l}\text { Hospialization per } \\
\text { patient }\end{array}$ & & 1.36 & & & & 40 & & & 1.61 & & & & & \\
\hline
\end{tabular}

BMI: body mass index; MELD: Model of End-Stage Liver Disease; ICU: intensive care unit; HCV: hepatitis C virus; HCC: hepatocellular carcinoma 
226,865 units of medicines and drugs $(35.2 \%$ of total cost). The main resources, quantities and average values are shown in Table 2.

The total expenditure for each MELD score group, the total cost, and percentage of the total expenditure of main resources are shown in Table 3.
The total cost of patients on the waiting list for liver transplantation was higher in those with MELD score between 25 and 30 (US\$ 16,686.74 $\pm 16,105.02$ ) and lower among those with MELD below 17 (US\$ 5,703.22 $\pm 9,318.68$ ). However, such average totals are directed related to the length of stay of patients in the hospital.

TABLE 2. Direct Costs of procedures and treatments. Total number and average unit cost of main resources utilized of patients on waiting list for liver transplant. (US\$)

\begin{tabular}{|c|c|c|c|c|c|c|c|c|c|}
\hline & \multicolumn{4}{|c|}{ Outpatient } & & \multicolumn{4}{|c|}{ Inpatient } \\
\hline & $\begin{array}{c}\text { Total } \\
\text { amount }\end{array}$ & $\begin{array}{l}\text { Unit } \\
\text { Price }\end{array}$ & Total Cost & $\%$ & & $\begin{array}{c}\text { Total } \\
\text { amount }\end{array}$ & $\begin{array}{l}\text { Unit } \\
\text { Price }\end{array}$ & Total Cost & $\%$ \\
\hline Human Resources & & & & & Hospitalization & & & & \\
\hline Psicology & 1,506 & 11.88 & $17,891.28$ & 0.91 & ICU days & 1,014 & 527.20 & $534,580.80$ & 13.03 \\
\hline Nutitionist & 600 & 9.22 & $5,532.00$ & 0.28 & Laboratoryal tests* & 275,043 & 2.03 & $558,336.60$ & 13.61 \\
\hline Odontologist & 295 & 14.12 & $4,165.40$ & 0.21 & Image exams & & & & \\
\hline Laboratory tests* & & & & & $\mathrm{CT}$ & 204 & 152.13 & $31,034.52$ & 0.75 \\
\hline Laboratoty tests & 164,498 & 2.03 & $333,930.94$ & 16.99 & US & 258 & 95.47 & $24,631.26$ & 0.60 \\
\hline Image exams & & & & & $\mathrm{XR}$ & 1,082 & 21.03 & $22,754.46$ & 0.55 \\
\hline Colangiography & 39 & 922.32 & $35,970.48$ & 1.83 & Other* & 255 & 148.66 & $37,908.30$ & 0.91 \\
\hline MNR & 85 & 385.90 & $32,801.50$ & 1.67 & Food/Meal/Diet & 4,720 & 25.78 & $121,681.60$ & 2.96 \\
\hline $\mathrm{CT}$ & 249 & 152.24 & $37,907.76$ & 1.93 & Consumables* & 67,590 & 3.85 & $260,221.50$ & 5.34 \\
\hline Other* & 892 & 139.99 & $124,871.08$ & 6.35 & Imunosupress* & 2,870 & 3.82 & $2,528.63$ & 0.06 \\
\hline Medicines & & & & & Heart drugs* & 16,087 & 17.30 & $172,943.41$ & 4.21 \\
\hline ATB* & 102,688 & 30.37 & $13,237.61$ & 0.68 & Gastric Drugs* & 25,524 & 0.38 & $25,253.83$ & 0.61 \\
\hline Ativirals* & 27,537 & 7.18 & $114,195.10$ & 5.82 & Antiinflamatories* & 4,376 & 5.99 & $25,175.39$ & 0.61 \\
\hline Immunosuppressants* & 161,300 & 3.76 & $209,924.39$ & 10.69 & Other & 153,617 & 5.48 & $836,897.67$ & 19.47 \\
\hline Heart drugs* & 128,995 & 0.62 & $13,056.62$ & 0.67 & HCC management & & & & \\
\hline Gastric Drugs* & 836,942 & 1.05 & $31,132.35$ & 1.59 & Chemoembolization & 59 & $2,750.74$ & $162,293.66$ & 3.96 \\
\hline Anti-inflamatories* & 69,527 & 0.20 & $18,465.30$ & 0.94 & Radiofrequency Abblation & 26 & $4,818.04$ & $125,269.04$ & 3.06 \\
\hline Other & $1,735,220$ & 2.46 & $470,031.36$ & 23.92 & Hemotherapy & & & & \\
\hline Paracentesis & & & & & Plasma & 576 & 145.92 & $84,049.92$ & 2.05 \\
\hline Paracenthesis & 631 & 112,78 & $71,164.18$ & 3.62 & Red Blood cells & 531 & 153.14 & $81,317.34$ & 1.98 \\
\hline Albumin units & 3,207 & 37,56 & $120,454.92$ & 6.13 & Platelets & 280 & 153.15 & $42,882.00$ & 1.05 \\
\hline
\end{tabular}

*Average cost. MNR: magnetic nuclear resonance; CT: computed tomography; US: ultrasound; ATB: antibiotics; ICU: intensive care unit

TABLE 3. Total expenditure of each MELD score group. (US\$)

\begin{tabular}{|c|c|c|c|c|c|c|c|c|c|}
\hline & \multicolumn{2}{|c|}{$\begin{array}{c}\text { MELD }<=17 \\
(\mathrm{~N}=132-27.39 \%)\end{array}$} & \multicolumn{2}{|c|}{$\begin{array}{c}\text { MELD 18-24 } \\
(\mathrm{N}=122-25.31 \%)\end{array}$} & \multicolumn{2}{|c|}{$\begin{array}{c}\text { MELD 25-30 } \\
(\mathrm{N}=113-23.44 \%)\end{array}$} & \multicolumn{2}{|c|}{$\begin{array}{c}\text { MELD > 30 } \\
(\mathrm{N}=115-23.86 \%)\end{array}$} & \multirow[b]{2}{*}{$P$ Value } \\
\hline & Total & $\%$ & Total & $\%$ & Total & $\%$ & Total & $\%$ & \\
\hline Total expenditure & $781,341.78$ & 12.9 & $1,505,437.37$ & 24.8 & $1,918,974.48$ & 31.6 & $1,859,232.88$ & 30.7 & $<0.001$ \\
\hline Intensive care & $408,047.61$ & 10.0 & $985,472.04$ & 24.0 & $1,333,697.64$ & 32.5 & $1,372,723.70$ & 33.5 & $<0.001$ \\
\hline Consumables & $31,986.33$ & 12.3 & $71,138.08$ & 27.3 & $75,022.40$ & 28.8 & $82,382.33$ & 31.6 & 0.21 \\
\hline HCC management & $2,750.74$ & 0.7 & $96,330.48$ & 23.7 & $207,489.52$ & 51.0 & $100,335.77$ & 24.7 & 0.11 \\
\hline Image exams & $82,742.28$ & 15.7 & $108,182.78$ & 20.5 & $228,050.67$ & 43.2 & $108,519.01$ & 20.6 & 0.27 \\
\hline Laboratorial tests & $127,156.69$ & 14.3 & $221,827.49$ & 24.9 & $287,428.54$ & 32.2 & $255,855.21$ & 28.7 & 0.01 \\
\hline Professional services & $113,385.93$ & 8.6 & $359,439.82$ & 27.3 & $412,219.04$ & 31.3 & $431,575.28$ & 32.8 & 0.01 \\
\hline
\end{tabular}

MELD: Model of End-Stage Liver Disease; HCC: hepatocellular carcinoma 
In this way, the cost/day related to each MELD group shows the relationship between the severity of disease and the costs over the time. We found that the more severe the patient, the greater its cost. The highest cost/day was found in those patients who had MELD $>30$ (US\$ 566.33 $\pm 1,083.92$ ) followed by those with MELD 25-30 (US\$167.29 \pm 330.52 ). The total average cost per patient for each MELD score group are shown in Table 4.

\section{DISCUSSION}

Patients on the waiting list for liver transplantation are subject to a series of complications and intercurrences that lead to the need for hospitalizations and procedures that increase the costs of care ${ }^{(17)}$. This is the first prospective cohort study that has used a micro-costing methodology for the analysis of the total cost of patients on the waiting list for liver transplantation. Most studies, to date, do not address the patient's total costs, and these high costs cannot be overlooked ${ }^{(2)}$.

A standard methodology in micro-costing was used so that accuracy of each patient costs was improved. This procedure intended to ensure that the cost differences were related to real clinical practice and not to data acquisition failures or general averages.

In our study, we found that more severe patients have a substantially higher cost than less severe patients. Studies addressing

TABLE 4. Health Cost of Waiting List. Main resources utilization of patients on waiting list for liver transplantation divided by MELD score group. (US\$)

\begin{tabular}{|c|c|c|c|c|c|c|c|c|c|c|c|c|c|}
\hline & \multicolumn{3}{|c|}{$\begin{array}{c}\text { MELD }<=17 \\
(\mathrm{n}=132-27.39 \%)\end{array}$} & \multicolumn{3}{|c|}{$\begin{array}{c}\text { MELD } 18-24 \\
(\mathrm{n}=122-25.31 \%)\end{array}$} & \multicolumn{3}{|c|}{$\begin{array}{c}\text { MELD } 25-30 \\
(\mathrm{n}=113-23.44 \%)\end{array}$} & \multicolumn{3}{|c|}{$\begin{array}{c}\text { MELD > } 30 \\
(\mathrm{n}=115-23.86 \%)\end{array}$} & \multirow[b]{2}{*}{$P$ Value } \\
\hline & Average & SD & Range & Average & SD & Range & Average & $\mathrm{SD}$ & Range & Average & SD & Range & \\
\hline Total cost ${ }^{1}$ & $5,703.22$ & $9,318.68$ & $\begin{array}{c}(27.50- \\
72,779.94)\end{array}$ & $12,140.62$ & $14,023.33$ & $\begin{array}{c}(79.00- \\
60,248.56)\end{array}$ & $13,686.73$ & $16,105.03$ & $\begin{array}{c}(168.16- \\
78,052.91)\end{array}$ & $16,027.87$ & $13,360.86$ & $\begin{array}{c}(27.53- \\
76,054.74)\end{array}$ & $<0.001$ \\
\hline Cost $/$ Day $^{2}$ & 59.52 & 302.90 & $\begin{array}{c}(3.49- \\
2,911.18)\end{array}$ & 131.52 & 457.32 & $\begin{array}{c}(9.04- \\
4,772.75)\end{array}$ & 167.29 & 330.52 & $\begin{array}{c}(14.87- \\
2,138.54)\end{array}$ & 566.33 & $1,083.92$ & $\begin{array}{c}(45.86- \\
8,803.03)\end{array}$ & $<0.001$ \\
\hline Outpatient ${ }^{3}$ & $2,724.77$ & $4,484.39$ & $\begin{array}{c}(27.50- \\
32,229.22)\end{array}$ & $4,193.27$ & $5,554.37$ & $\begin{array}{c}(42.09- \\
23,415.90)\end{array}$ & $5,089.36$ & $5,264.92$ & $\begin{array}{c}(92.00- \\
27,196.40)\end{array}$ & $4,194.04$ & $4,849.88$ & $\begin{array}{c}(27.53- \\
24,753.02)\end{array}$ & $<0.001$ \\
\hline Intensive Care ${ }^{4}$ & $9,273.81$ & $12,644.35$ & $\begin{array}{c}(637.12- \\
71,970.76)\end{array}$ & $14,282.20$ & $14,015.09$ & $\begin{array}{c}(456.42- \\
51,864.73)\end{array}$ & $16,068.65$ & $16,266.55$ & $\begin{array}{c}(217.76- \\
77,488.56)\end{array}$ & $16,149.69$ & $13,688.30$ & $\begin{array}{c}(820.58- \\
72,873.02)\end{array}$ & $<0.001$ \\
\hline $\begin{array}{l}\text { Hospitalization/ } \\
\text { days }\end{array}$ & 802.71 & 412.59 & $\begin{array}{l}(404.81- \\
2,551.40)\end{array}$ & 837.32 & 620.59 & $\begin{array}{l}(340.28- \\
3,633.74)\end{array}$ & 971.29 & 635.27 & $\begin{array}{l}(182.35- \\
3,928.78)\end{array}$ & $1,048.51$ & 682.34 & $\begin{array}{l}(242.31- \\
4,757.68)\end{array}$ & 0.04 \\
\hline Consumables & 743.87 & 902.28 & $\begin{array}{l}(112.23- \\
4,152.61)\end{array}$ & $1,147.39$ & $1,275.63$ & $\begin{array}{c}(56.12- \\
5,611.64)\end{array}$ & $1,119.74$ & $1,362.47$ & $\begin{array}{c}(56.12- \\
6,397.27)\end{array}$ & $1,069.90$ & $1,088.45$ & $\begin{array}{c}(56.12- \\
7,575.71)\end{array}$ & 0.21 \\
\hline Medicines $^{6}$ & $2,111.50$ & $2,612.51$ & $\begin{array}{c}(150.74- \\
11,895.53)\end{array}$ & $3,454.85$ & $4,275.12$ & $\begin{array}{c}(160.75- \\
18,599.51)\end{array}$ & $2,954.77$ & $3,781.07$ & $\begin{array}{c}(76.77- \\
13,342.28)\end{array}$ & $3,285.76$ & $3,855.36$ & $\begin{array}{c}(30.92- \\
21,701.30)\end{array}$ & $<0.05$ \\
\hline Hemotherapy $^{7}$ & $1,289.54$ & $1,436.39$ & $\begin{array}{l}(145.92- \\
4,170.36)\end{array}$ & $1,923.39$ & $1,963.27$ & $\begin{array}{c}(160.37- \\
8,795.67)\end{array}$ & $2,172.46$ & $2,090.69$ & $\begin{array}{l}(145.92- \\
7,854.78)\end{array}$ & $3,750.89$ & $3,047.91$ & $\begin{array}{c}(291.84- \\
13,896.59)\end{array}$ & $<0.001$ \\
\hline $\begin{array}{l}\text { HCC } \\
\text { management }\end{array}$ & $2,750.74$ & $2,750.74$ & $(2.750,74)$ & $10,703.39$ & $7,193.46$ & $\begin{array}{l}(2750.74- \\
26,504.76)\end{array}$ & $7,154.81$ & $5,402.47$ & $\begin{array}{l}(1094.11- \\
22,948.17)\end{array}$ & $7,718.14$ & $11,457.53$ & $\begin{array}{c}(820.58- \\
45,092.72)\end{array}$ & 0.11 \\
\hline Image exams & $1,103.23$ & $1,545.86$ & $\begin{array}{c}(295.36- \\
10,796.52)\end{array}$ & $1,257.94$ & $1,439.40$ & $\begin{array}{c}(2.34- \\
6,184.76)\end{array}$ & $2,375.53$ & $3,345.47$ & $\begin{array}{c}(2.34- \\
17,758.22)\end{array}$ & $1,409.34$ & $1,793.86$ & $\begin{array}{c}(2.34- \\
7,635.93)\end{array}$ & 0.27 \\
\hline $\begin{array}{l}\text { Laboratorial } \\
\text { tests }^{8}\end{array}$ & 934.98 & 968.49 & $\begin{array}{c}(11.65- \\
5,864.75)\end{array}$ & $1,833.29$ & $1,872.24$ & $\begin{array}{c}(37.93- \\
7,781.85)\end{array}$ & $2,499.38$ & $2,744.09$ & $\begin{array}{c}(46.76- \\
18,856.05)\end{array}$ & $2,224.83$ & $1,992.34$ & $\begin{array}{c}(31.68- \\
10,944.37)\end{array}$ & 0.01 \\
\hline $\begin{array}{l}\text { Professional } \\
\text { services }^{9}\end{array}$ & $2,699.67$ & $4,427.65$ & $\begin{array}{c}(273.53- \\
24,566.77)\end{array}$ & $4,528.95$ & $5,249.86$ & $\begin{array}{c}(136.76- \\
20,351.33)\end{array}$ & $4,867.97$ & $6,367.69$ & $\begin{array}{c}(136.76- \\
27,553.52)\end{array}$ & $4,938.77$ & $4,331.79$ & $\begin{array}{c}(136.76- \\
18,463.06)\end{array}$ & 0.01 \\
\hline
\end{tabular}

MELD: Model of End-Stage Liver Disease; HCC: Hepatocelullar Carcinoma; $P$ value of all groups (Kruskal-Wallis test). $P$ Value inter-groups (Non-Parametric Tukey test)

1. MELD < $=17$ and MELD 18-24 $(P<0.001)$; MELD < $=17$ and MELD 25-30 $(P<0.001)$; MELD $<=17$ and MELD $>30(P<0.001) ;$ MELD 18-24 and MELD 25-30 $(P=0.002) ;$ MELD 18-24 and $\mathrm{MELD}>30(P=0.001)$,

2: MELD < $=17$ and MELD 18-24 ( $P<0.001)$; MELD < $=17$ and MELD 25-30 $(P<0.001) ;$ MELD $<=17$ and MELD $>30(P<0.001)$; MELD 18-24 and MELD 25-30 $(P=0.046)$; MELD 18-24 and MELD $>30(P<0.001)$; MELD $25-30$ and MELD $>30(P<0.001)$

3: MELD $<=17$ and MELD 18-24 $(P=0.017)$; MELD $<=17$ and MELD 25-30 $(P<0.001) ;$ MELD $<=17$ and MELD $>30(P=0.026) ;$ MELD 18-24 and MELD 25-30 $(P=0.029)$

4: MELD $<=17$ and MELD 25-30 $(P=0.005) ;$ MELD $<=17$ and MELD $>30(P<0.001)$.

5: MELD $<=17$ and MELD 18-24 ( $P=0.012) ;$ MELD $<=17$ and MELD 25-30 $(P=0.001)$; MELD $<=17$ and MELD $>30(P<0.001) ;$ MELD $18-24$ and MELD $>30(P<0.001) ;$ MELD 25-30 and MELD $>30(P<0.001)$

6: MELD < $=17$ and MELD 18-24 $(P=0.001) ;$ MELD $<=17$ and MELD 25-30 $(P<0.001)$; MELD $<=17$ and MELD $>30(P<0.001)$; MELD 18-24 and MELD $>30(P=0.003)$; MELD 25-30 and MELD $>30(P=0.049)$

7: MELD $<=17$ and MELD $>30(P=0.006)$; MELD 18-24 and MELD $>30(P=0.032)$

8: MELD $<=17$ and MELD 18-24 $(P<0.001)$; MELD $<=17$ and MELD 25-30 $(P<0.001)$; MELD $<=17$ and MELD $>30(P<0.001)$; MELD 18-24 and MELD 25-30 $(P=0.036)$

9: MELD $<=17$ and MELD $>30(P=0.002)$. 
the relationship between patient costs and MELD have already pointed to this causal relationship ${ }^{(18,46)}$. We also found that high costs are the result of a series of complications and intercurrences that lead to a greater number of hospitalizations and high-cost procedures $^{(13,17,20)}$.

Although the total cost of patient care in our study was considered low, averaging just over US\$ 12,000, compared to studies showing the annual cost of about US\$20,000 in HCV patient care, we found that the cost of treating the most severely ill patient may exceed the costs of liver transplantation ${ }^{(26,30)}$. Currently, the management of the patient in the list is aimed at maintaining the patient's health until the moment of transplantation and more effective and preventive actions can reduce the number of complications and hospitalizations.

Hemocomponents are a vital but expensive resource with a high increase in total cost. In patients with MELD $>30$, this cost is approximately $22 \%$ of the total cost and five times higher than in patients with MELD $<=17$. Studies addressing the cost of replacement of blood components are rare, however we observed in a recent study that the cost of the blood component per bag in Brazil (approximately US\$ 300) is similar to values found in other studies, ranging from US\$ 210 to US\$ $338^{(6,16,24,43)}$. Coelho et al. showed that the replacement of blood components represented about $41 \%$ of the total $\operatorname{cost}^{(6)}$.

In our study, the cost of human resources was $15 \%$ in the outpatient clinic and $26 \%$ in hospitalizations, similar to other public hospitals in Brazil ${ }^{(32)}$. McAdam found costs related to human resources to be $19.8 \%$ and $23.3 \%$ of total costs ${ }^{(26)}$. In another study, Oroz mentions that $32 \%$ to $44 \%$ of total costs are related to human resources, in the United States and OECD countries respectively ${ }^{(31)}$.

Materials and drugs accounted for $9.9 \%$ and $26.8 \%$ respectively of the total costs per patient. The use of high-cost drugs for the treatment of the patient in the list raises the costs of this resource. In developed countries, this value represents a lower percentage in relation to the total costs per patient, between $12.5 \%$ and $13.7 \%$ with unstable cirrhosis and $\mathrm{CHC}$ patients, respectively ${ }^{(26)}$.

Treatment of patients with hepatocellular carcinoma causes a large impact on the total cost of these patients, with an average of US\$ 7700 (the second most relevant resource in total costs). In other studies, this figure reaches US\$20,000 per year ${ }^{(25)}$. Despite the high cost, treatment of hepatocellular carcinoma is a cost-effective procedure, recommended for the cure and withdrawal of the patient from the waiting list for transplantation, in other settings ${ }^{(25)}$.

Patients with MELD 25-30 accounted for $31.6 \%$ of the total costs, $51 \%$ of all costs in HCC management, $43.2 \%$ of the total expenditure in image exams and $32.2 \%$ of all costs in laboratorial tests. These MELD group patients had 2.0, 2.2 and 75.4 times higher costs related to HCC management than those with MELD $>30,18-24$ and $<=17$ respectively.

Patients with MELD >30 accounted for $30.7 \%$ of the total costs, $33.5 \%$ of hospitalization costs, $56.8 \%$ of costs with blood components, and $34.3 \%$ of drug costs. These MELD patients had 2.6, 3.4 and 11.6 times higher costs related to replacement of blood components when compared to patients with MELD 25-30, 18-24 and $<=17$ respectively.

The data presented in this study had some limitations that should be highlighted. All resources were calculated using the hospital costs, thus market values were not considered. This methodology can limit the comparison with other studies or with the costs of others hospitals. Furthermore, we decided not to use governmental reimbursement or similar tables of costs, because this could underestimate the cost data presented. The MELD value of each patient was calculated at the time of the inclusion on the waiting list or at the time of hospitalization. This procedure was necessary for the formation of MELD groups and posterior comparisons. The MELD evolution of each patient would be very difficult to perform in this study, but this is an important perspective for future studies.

When we analyzed the time length on the list, in relation to the cost/day and the total cost from each MELD score group, we found that the more severe patients remained less time on the list, but presented the highest cost/day. Considering the cost/day, patients with MELD $>30$ have cost/day 9.5 and 4.3 times more expensive than those with MELD $<17$ and 18-24, respectively. Thus, it is possible to understand that, if the time on list of the more severe patients were longer, the total cost would be even higher, causing a high impact in the limited healthcare budgets.

Although, the data presented can be used as a subsidy for better use of resources in the treatment of patients on the waiting list for liver transplantation and can provide important information, regarding frequency of complications, the percentage of resources and expenditures related to the severity of health status.

\section{CONCLUSION}

The patient's waiting list cost for liver transplantation increases as the patient's severity increases. Procedures related to the treatment of the patient with hepatocellular carcinoma, the use of blood components and hospitalizations are the main cost drivers for the health care of these patients. As costs increase through time, it is also expected that the longer the time on waiting list, the higher the total costs and higher will be the economic impact in the limited healthcare budgets.

\section{ACKNOWLEDGEMENTS}

We would like to thank all the members of HC-FM-USP and ICESP who helped us to develop this microcosting study for the patients on the waiting list. The authors would also like to acknowledge the professors Patrícia Coelho, Andréa Tenório and Juliana Yukari from Preventive Medicine Department of Sao Paulo Medical School for the explanations of how to interpret the data and how to better present the results.

\section{Authors' contributions}

Turri JAO, Decimoni TC, Ferreira LA, Diniz MA, Haddad LBP, Campolina AG: substantial contributions to the conception or design of the work; acquisition, analysis, and interpretation of data for the work. Drafting the work and revising it critically for important intellectual content and final approval of the version to be published. Agreement to be accountable for all aspects of the work in ensuring that questions related to the accuracy or integrity of any part of the work are appropriately investigated and resolved. 
Turri JAO, Decimoni TC, Ferreira LA, Diniz MA, Haddad LBP, Campolina AG. Altos valores de MELD aumentam o custo total em lista de espera para o transplante hepático. Um estudo de microcusteio. Arq Gastroenterol. 2017;54(3):238-45.

RESUMO - Contexto - O período pré-transplante é complexo e inclui grande quantidade de procedimentos. A gravidade da doença hepática predispõe a um alto número de internações e procedimentos de alto custo. Estudos em avaliação econômica são uma importante ferramenta para o manejo dos custos em lista de espera para o transplante hepático. Objetivo - O objetivo do presente estudo foi avaliar o custo total do paciente em lista de espera para o transplante hepático e os principais recursos relacionados ao alto custo. Métodos - Foi realizado um estudo de coorte em 482 pacientes registrados em lista de espera para o transplante hepático. Os pacientes foram acompanhados por um período de 24 meses, no qual foram avaliados todos os custos de materiais, medicamentos, consultas, procedimentos internações, exames laboratoriais e de imagem, reposição de hemocomponentes e nutrição recebida. A quantidade total de cada recurso e componente utilizado foi obtida e multiplicada pelo seu valor unitário e, desta maneira, o custo individual de cada paciente foi obtido. Resultados - O total gasto pelos 482 pacientes foi de US\$ 6.064.986,51. Os custos ambulatoriais corresponderam a $32,4 \%$ do total (US\$ $1.965 .045,52$ ) e os custos em internação corresponderam a 67,6\% do total (US\$ 4.099.940,99). Os principais determinantes do custo em ambulatório foram: medicamentos (44,31\%) e exames laboratoriais e de imagem (31,68\%). Os principais determinantes de custo em internações foram: medicamentos (35,20\%), utilização do leito em enfermaria e em UTI (26,38\%) e exames laboratoriais (13,72\%) Pacientes com valores de MELD entre 25-30 foram os de maiores custos em lista de espera (US\$16.686,74 $\pm 16,105.02$ ) e os de menor custo foram os pacientes com MELD abaixo de 17 (US\$ 5.703,22 \pm 9.318,68). Conclusão - O custo total em lista de espera para o transplante hepático aumenta de acordo com a gravidade do paciente. Individualmente, internações, reposição de hemocomponentes e o tratamento do paciente com carcinoma hepatocelular são os principais determinantes de custo para os pacientes em lista de espera para o transplante hepático. Quanto maior o tempo de espera, maiores serão os custos em lista, causando maior impacto nos sistemas de saúde.

DESCRITORES - Avaliação em saúde. Custos e análise de custo. Listas de espera. Transplante de fígado.

\section{REFERENCES}

1. Bodzin AS, Busuttil RW. Hepatocellular carcinoma: advances in diagnosis, management, and long-term outcome. World J Hepatol. 2015;7:1157-67.

2. Brand DA, Viola D, Rampersaud P, Patrick PA, Rosenthal WS, Wolf DC. Waiting for a liver--hidden costs of the organ shortage. Liver Transpl. 2004;10:1001-10.

3. Buchanan P, Dzebisashvili N, Lentine KL, Axelrod DA, Schnitzler MA, Salvalaggio PR. Liver transplantation cost in the model for end-stage liver disease era: looking beyond the transplant admission. Liver Transplant. 2009;15:1270-77.

4. Carrillo FJ, Mattos AA, Vianey AF, Vezozzo DC, Marinho F, et al. Brazilian society of hepatology recommendations for the diagnosis and treatment of hepatocellular carcinoma. Arq Gastroenterol. 2015;52:2-14.

5. Charles JM, Edwards RT, Bywater T, Hutchings J. Micro-costing in public health economics: steps towards a standardized framework, using the incredible years toddler parenting program as a worked example. Prev. Sci; 2013, pp. 377-89.

6. Coelho JCU, Wiederkehr JC, Lacerda MA, Campos ACL, Zeni Neto C, et al. Custo do transplante hepático no hospital de clínicas da universidade federal do Paraná. Rev Assoc Med Bras. 1997;43:53-7.

7. Drummond MF, Sculpher MJ, Claxton K, Stoddard GL, Torrance GW. Methods for the economic evaluation of health care programmes. Oxford: Oxford University Press, 1987.

8. Drummond MF. Economic evaluation of treatment strategies in gastroenterology. Am J Gastroenterol. 2005;100:2143-5.

9. Drummond MF, Sculpher MJ, Torrance GW, O’Brien BJ, Stoddart GL. Methods for the economic evaluation of health care programmes, second edition. By Oxford: Oxford University Press, 1997. Vol. 2. 43 pp.

10. Drummond MF, Sculpher MJ, Torrance GW, O’Brien BJ, Stoddart GL. Critical assessment of economic evaluation. In Method for the Economic Evaluation of Health Care Programmes. Oxford University Press. 2005, pp. 27-53.

11. El-Serag HB. Hepatocellular carcinoma: recent trends in the United States. Gastroenterology. 2004; 127:S27-34.

12. Farnsworth N, Fagan SP, Berger DH, Awad SS. 2004. Child-Turcotte-Pugh versus MELD score as a predictor of outcome after elective and emergent surgery in cirrhotic patients. Am J Surg. 188:580-83.

13. Fink MA, Berry SR, Gow PJ, Angus PW, Wang B-Z, et al. Risk factors for liver transplantation waiting list mortality. J Gastroenterol Hepatol. 2007;22:119-24.

14. Foxton MR, Al-Freah MAB, Portal AJ, Sizer E, Bernal W, et al. Increased MELD score at the time of liver transplant results in prolonged hospitalization and overall intensive care unit costs. Liver Transplant. 2010;16:668-7.

15. Fragoso AV, Pedroso MR, Herman P, Montagnini AL, et al. Comparing the enzyme replacement therapy cost in post pancreatectomy patients due to pancreatic tumor and chronic pancreatitis. Arq Gastroenterol. 2016;53:94-7.

16. Fragoulakis V, Stamoulis K, Grouzi E, Maniadakis N. The cost of blood collection in Greece: an economic analysis. Clin Ther. 2014;36:1028-36.e5.
17. Gambato M, Lens S, Navasa M, Forns X. Treatment options in patients with decompensated cirrhosis, pre- and post-transplantation. J Hepatol. 2014;61(1 Suppl):S120-31.

18. Gordon SC, Pockros PJ, Terrault NA, Hoop RS, Buikema A, et al. Impact of disease severity on healthcare costs in patients with chronic hepatitis $\mathrm{C}(\mathrm{CHC})$ virus infection. Hepatology. 2012;56:1651-60.

19. Heidelbaugh JJ, Bruderly M. Cirrhosis and chronic liver failure: part I. diagnosis and evaluation. Am Fam Physician. 2006;74:756-62.

20. Heidelbaugh JJ, Sherbondy M. Cirrhosis and chronic liver failure: part II. complications and treatment. Am Fam Physician. 2006;74:767-76.

21. Herman P, Lopes F de LM, Kruger JA, Fonseca GM, Jeismann VB, et al. Is resection of hepatocellular carcinoma in the era of liver transplantation worthwile? A single center experience. Arq Gastroenterol. 2016;53:169-74.

22. Jay CL, Skaro AI, Ladner DP, Wang E, Lyuksemburg V, et al. Comparative effectiveness of donation after cardiac death versus donation after brain death liver transplantation: recognizing who can benefit. Liver Transplant. 2012;18: $630-40$.

23. Johnston K, Buxton M, Jones D, Fitzpatrick R. Assessing the costs of healthcare technologies in clinical trials. Health Technol Assess. (Rockv). 1999;3:1-76.

24. Kanavos P, Yfantopoulos J, Vandoros C, Politis C. The economics of blood: gift of life or a commodity? Int J Technol Assess Health Care. 2006;22:338-43.

25. Llovet JM, Mas X, Aponte JJ, Fuster J, Navasa M, et al. Cost effectiveness of adjuvant therapy for hepatocellular carcinoma during the waiting list for liver transplantation. Gut. 2002;50:123-8.

26. McAdam-Marx C, McGarry LJ, Hane CA, Biskupiak J, Deniz B, Brixner DI. Allcause and incremental per patient per year cost associated with chronic hepatitis $\mathrm{C}$ virus and associated liver complications in the United States: a managed care perspective. J Manag Care Pharm. 2011;17:531-46.

27. Merion RM, Schaubel DE, Dykstra DM, Freeman RB, Port FK, Wolfe RA. The survival benefit of liver transplantation. Am J Transplant. 2005;5(September 2004):307-13.

28. Mishra A, Otgonsuren M, Venkatesan C, Afendy M, Erario M, Younossi ZM. The inpatient economic and mortality impact of hepatocellular carcinoma from 2005 to 2009: analysis of the US nationwide inpatient sample. Liver Int. 2013;33:1281-86.

29. Myers RP, Krajden M, Bilodeau M, Kaita K, Marotta P, et al. Burden of disease and cost of chronic hepatitis C infection in Canada. Can. J Gastroenterol Hepatol. 2014;28:243-50.

30. Neff GW, Duncan CW, Schiff ER. 2011. The current economic burden of cirrhosis. Gastroenterol Hepatol. 7:661-71.

31. Orosz E. The OECD System of Health Accounts and the US National Health. 2005. 
32. Portela MP, Neri EDR, Fonteles MMF, Garcia JHP, Fernandes MEP. O custo do transplante hepático em um hospital universitário do Brasil. Rev Assoc Med Bras. 2010; 56:322-6.

33. R Core Team. R: A language and environment for statistical computing. 2014 Available from: http://www.r-project.org

34. Rajendra A, Wong JB. Economics of chronic hepatitis B and hepatitis C. J. Hepatol. 2007,47:608-17.

35. Razavi H, Waked I, Sarrazin C, Myers RP, Idilman R, et al. The present and future disease burden of hepatitis $\mathrm{C}$ virus $(\mathrm{HCV})$ infection with today's treatment paradigm. J Viral Hepat. 2014;21(Suppl):34-59.

36. Santos R, Miyazaki MCOS, Domingos NAM, Valério NI, Silva RF, Silva RCMA. Patients undergoing liver transplantation: psychosocial characteristics, depressive symptoms, and quality of life. Transplant. Proc. 2008;40:802-4.

37. Secoli SR, Nita ME, Ono-Nita SK, Nobre M. Avaliação de tecnologia em saúde: II. A análise de custo-efetividade. Arq. Gastroenterol. 2010;47:329-33.

38. Soárez PC de, Novaes HMD, Sartori AMC. Impact of methodology on the results of economic evaluations of varicella vaccination programs: is it important for decision-making? Cad Saúde Pública. 2009;25(Suppl 3):S401-14.

39. Swan Tan S, Bakker J, Hoogendoorn ME, Kapila A, Martin J, et al. Direct cost analysis of intensive care unit stay in four European countries: applying a standardized costing methodology. Value Heal. 2012, pp. 81-6.

40. Tan SS, Hakkaart-van Roijen L, Al MJ, Bouwmans CA, Hoogendoorn ME, et al. A microcosting study of intensive care unit stay in the Netherlands. J Intensive Care Med. 2008;23:250-7.
41. Teh SH, Nagorney DM, Stevens SR, Offord KP, Therneau TM, et al. Risk factors for mortality after surgery in patients with cirrhosis. Gastroenterology. 2007;132:1261-9.

42. Teixeira UF, Goldoni MB, Machry MC, Ceccon PN, Fontes PR, et al. Ambulatory laparoscopic cholecystectomy is safe and cost-effective: a brazilian single center experience. Arq Gastroenterol. 2016;53:103-7.

43. Tretiak R, Laupacis A, Rivière M, McKerracher K, Souêtre E. Cost of allogeneic and autologous blood transfusion in Canada. Canadian cost of transfusion study group. CMAJ. 1996;154:1501-8.

44. Vonlanthen R, Slankamenac K, Breitenstein S, Puhan MA., Muller MK, et al. The impact of complications on costs of major surgical procedures. Ann Surg. 2011;254:907-13.

45. Wanna AGB, Noble JH, Carlson ML, Gifford H, Dietrich MS, et al. Chronic hepatitis $\mathrm{C}$ virus (HCV) disease burden and cost in the United States. Laryngoscope, 2014, pp. 2-31.

46. Washburn WK, Pollock BH, Nichols L, Speeg K V, Halff G. Impact of recipient meld score on resource utilization. Am J Transplant. 2006;6:2449-54.

47. Wong G, Howard K, Webster AC, Morton RL, Chapman JR, Craig JC. How is health economics relevant to transplant clinicians? Transplantation. 2014;98:124-30.

48. Xu X, Grossetta Nardini HK, Prah Ruger J. Micro-costing studies in the health and medical literature: protocol for a systematic review. Syst Rev. 2014;3:1-7.

49. Zalesak M, Francis K, Gedeon A, Gillis J, Hvidsten K, et al. Current and future disease progression of the chronic HCV population in the United States. PLoS One. 2013;8:e63959. 